\title{
YHTEISTOIMINTA MAANVILJELIJÖIDEN VÄLILLÄ
}

\author{
Kauko Honkala \\ Institutet för samhällsforskning Åbo Akademi
}

Saapunut 20.7. 1968

Maanviljelijöiden välinen yhteistoiminta on maassamme kenties yhtä vanhaa kuin maatalous elannon tarjoavana ammattina. Ainakin jo 1500-luvulta on kirkonmiesten muistiinpanoja talonpoikien yhteisistä toimista. Seuraavina vuosisatoina laki jopa velvoitti taloja yksissä tuumin ylläpitämään teitä, siltoja jne. Maatalousjärjestelmä sinänsäkin oli omiaan ylläpitämään yhteistoimintaa, olihan sarkajakoisella pellolla pakko päästä yhteisymmärrykseen peltotöiden suorittamisesta.

Historian lähteet kertovat myös naapuriavusta, jota annettiin mm. työliiton tai talkoitten muodossa. Työliitot olivat lähinaapureiden tai sukulaisten muodostamia ryhmiä, joissa työtä vaihdettiin: mentiin naapuriin ja saatiin sitten sieltä työvoimaa takaisin. Talkoissa ei niinkään ollut kysymyksessä työn maksaminen työllä, pikemminkin työ korvattiin kestityksellä, mutta talkoihin osallistumiseen kyllä vaikutti molemminpuolisen velvoituksen tuntukin. $\mathbf{1})$

Vanhaa agraariyhteiskuntaa rupesi 1700-luvun puolivälistä alkaen vähitellen hajoittamaan ensin isojako ja sitten seuraavalla vuosisadalla teollistumisen nimellä tunnettu laajaalainen muutos. Teollistumista seurasi myös heikko individualismin tuulahdus, mikä vaikutti samaan suuntaan kuin iso- ja uusjakokin. Talonpoikien välisen yhteistoiminnan edellytykset, sen maaperä vähitellen huononi, mutta siitä huolimatta tämä perinne on elänyt meidän päiviimme saakka. Sen sisältö ja muodot ovat ehkä muuttuneet, koska elinympäristökin on toinen. Yhä kumminkin perinne elää $\left.{ }^{2}\right)$.

Seuraavassa esitettävän tutkimuksen tarkoituksena on selvittää, missä muodossa ja kuinka voimakkaana tämä perinteeseen nojautuva, mutta eräässä mielessä kovin ajankohtainen maanviljelijöiden välinen yhteistoiminta esiintyy nykyisen maatalousyhdyskunnan piirissä.

1) Jutikkala, Erno 1946. Suomen talonpoika kautta aikojen, s. 16-34. Helsinki.

2) Aaltonen, Esko 1964. Maaseudun kulttuuriperintö. Porvoo. 


\section{Tutkimusaineisto ja menetelmät}

Tutkimusaineisto kerättiin European Society for Rural Sociologyn toimeenpaneman kansainvälisen tutkimuksen Social Implications of Farm Mechanization yhteydessä. Tämä FAO:n Euroopan Komission aloitteesta syntynyt ja FAO:n ja UNESCO:n osittain rahoittama tutkimus suoritettiin samaa haastattelulomaketta käyttäen kaikkiaan yhdeksässä Euroopan maassa ja lisäksi USA:ssa. Tutkimusalueen valintakriteerien nojalla - perinnäistä ja vaurasta maanviljelysaluetta, jossa taajama- ja teollisuusväestön osuus on pieni ja joka sijaitsee suhteellisen kaukana suurista kaupungeista - meidän maassamme päädyttiin haastattelualueeksi valitsemaan Punkalaitumen kunta. Henkikirjoista poimittiin umpimähkäisesti 200 henkilöä, jotka olivat ammatikseen ilmoittaneet maanviljelijä tai pienviljelijä. Haastattelulomakkeen kysymykset pyrkivät selvittämään mm. tilalla suoritettuja uudistuksia, tilan tuotantoa, koneiden käyttöä, yhteistoimintaa muiden viljelijöiden kanssa, sekä viljelijöiden asenteita maatalouteen yleensä, koneellistamiseen ja maatalouden tulevaisuuteen.

Tutkimuksen suunnittelu aloitettiin 1965, kenttätyöt suoritettiin vuoden 1966-67 aikana, vuoden 1967 loppuun mennessä useimmat osallistujamaat olivat saaneet valmiiksi osatutkimuksiensa keskeisiä tuloksia esittelevän raportin, ja parhaillaan (1968) on kansainvälisen yhteenvedon valmistelu käynnissä.

Taulukko 1. Otoksen tilat peltoalan ja viljelijän iän mukaan.

Table 1. The farms according to arable area and age of farmer.

Peltoala hehtaaria
Arable area ha

\begin{tabular}{lllllll}
\multicolumn{6}{c}{ Viljelijän ikä vuosia Age of farmer } & Yht. \\
\cline { 1 - 3 }-24 & $25-34$ & $35-44$ & $45-54$ & $55-64$ & $65-$ & Total
\end{tabular}

\begin{tabular}{lrrrrrrr}
\hline & & & & & & 2 & 23 \\
$1-4.9$ & - & - & 3 & 8 & 10 & 11 & 65 \\
$5-9.9$ & - & 7 & 16 & 17 & 14 & 4 & 42 \\
$10-14.9$ & 1 & 1 & 11 & 16 & 10 & 4 & 18 \\
$15-19.9$ & - & 2 & 10 & 5 & 5 & 5 & 27 \\
$20-29.9$ & 2 & 5 & 4 & 2 & 4 & 1 & 18 \\
$30-49.9$ & - & 1 & 2 & 2 & 2 & - & 7 \\
$50-$ & 3 & 17 & 49 & 55 & 49 & 27 & 200 \\
\hline Yht. Total & & & & & &
\end{tabular}

Taulukko 1 esittelee haastateltua otosta. Sen summasarakkeesta nähdään erikokoisten viljelmien lukumäärä. Keskimääräinen peltoala on 15.6 ha ja metsäala noin 20 ha. Taulukon summariviltä taas nähdään eri ikäisten viljelijöiden lukumäärä. Otoksen viljelijöiden keski-ikä on 49 vuotta. Isännän ikä on keskimäärää korkeampi alle 30 ha:n tiloilla ja keskimäärää alhaisempi yli 30 ha:n tiloilla. Erityisen korkea keski-ikä, 57 vuotta, on alle 5 ha:n tilojen viljelijöillä.

Viljelijöistä n. $70 \%$ on käynyt vain kansakoulun, muutama ei sitäkään. Noin $30 \%$ on käynyt jotain koulua kansakoulun jälkeen. Tavallisin on maamieskoulu, sen käyneitä on $13 \%$ kaikista viljelijöistä. Koulusivistys korreloi vahvasti tilakoon kanssa: kun alle 5 ha:n tilojen isännistä $0 \%$ on käynyt muuta koulua kansakoulun jälkeen, ja 5-9 ha:n isännistä 
vain $7 \%$, ovat vastaavat prosenttiluvut $20-29$ ha:n tiloilla $35,30-49$ ha:n tiloilla 68 ja yli 50 ha:n tiloilla peräti 86 .

\section{Yhteistoimintaviljelijöiden piirteitä}

Jokaiselta haastateltavalta pyydettiin tietoja hänen yhteistoiminnastaan muiden viljelijöiden kanssa. Taulukko 2 luettelee ilmi tulleet yhteistoimintamuodot ja niiden lukuisuu-

Taulukko 2. Yhteistoimintamuodot ja niihin osallistuvien viljelijöiden lukumäärä.

Table 2. Fields of cooperation and number of participating farmers.

\begin{tabular}{lc}
\hline $\begin{array}{l}\text { Yhteistoimintamuoto } \\
\text { Field of cooperation }\end{array}$ & $\begin{array}{c}\text { Viljelijöiden lukumäärä } \\
\text { Number of farmers }\end{array}$ \\
\hline Työnvaihto Exchange of labor & 104 \\
Koneiden vaihto Exchange of machinery & 53 \\
Koneiden + työn vaihto Exchange of machinery + labor & 47 \\
Koneiden yhteisomistus Co-ownership of machinery & 90 \\
Yhteisosto Cooperative buying & 9 \\
Yhteislaidun Joint pasture & 6 \\
Yhteismetsä Joint forest & 9 \\
\hline Yhteensä Total & 318
\end{tabular}

den. Neljä listan ensimmäistä ovat yleisimpiä. Yhteisosto esiintyi vain yhdessä kylässä, jossa viljelijät olivat yksissä tuumin tilanneet vaununlastillisen lannoitteita. Yhteislaidun ja yhteismetsä eroavat periaatteessa muista, sillä ne eivät alun perin ole seurausta viljelijöiden spontaanista toiminnasta.

Työnvaihto tarkoittaa molemminpuolista auttamista ihmistyövoimaa vaativissa tilanteissa. Työ maksetaan työllä, rahaa ei käytetä. Samankaltaista rahalliseen korvaukseen nojautumatonta koneiden lainaamista tarkoittaa koneiden vaihto. Koneiden + työn vaihto tarkoittaa yhteistoimintaa, jossa koneen kuljettaja tai hoitaja seuraa konetta, se on siis eräässä mielessä kahden ensiksimainitun yhteismuoto. Koneiden yhteisomistus taas on kysymyksessä, jos kaksi tai useampia viljelijöitä ovat yhdessä hankkineet jonkin koneen, pitävät sitä yllä ja käyttävät tarvitessaan. Sen sijaan rahtiajo eli vuokrakäyttö, s.o. kustannusten täysimääräinen maksaminen rahalla ei kuulu tässä tarkoitettuun viljelijöiden väliseen yhteistoimintaan.

Sen perusteella moneenko eri yhteistoimintaryhmään viljelijä kuuluu, muodostetaan uusi muuttuja, jota seuraavassa tullaan kutsumaan yhteistoiminnallisuudeksi. Sen määrittely ja jakautuma on seuraava.

yhteistoiminnallisuus cooperativeness niiden yhteistoimintaryhmien luku, joihin viljelijă kuuluu number of groups of cooperation the farmer belongs to

0

1

2

3 t. us, or more viljelijöiden lukumäärä number of farmers 
Täysin syrjässä yhteistoiminnnasta on siis 46 viljelijää eli vajaa neljäsosa otoksesta, ja erittäin intensiivisesti harjoittaa yhteistoimintaa 42 viljelijää eli $21 \%$ olemalla vähintään kolmessa ryhmässä. Korreloimalla yhteistoiminnallisuutta muihin muuttujiin on seuraavassa tarkoitus etsiä piirteitä, jotka erottavat yhteistoiminnallisen viljelijän isännästä, joka on täysin syrjässä.

Taulukko 3. Tilojen prosenttinen jakautuma yhteistoiminnallisuuden ja peltoalan mukaan.

Table 3. Per cent distribution of farms according to cooperativeness and arable area.

\begin{tabular}{|c|c|c|c|c|}
\hline \multirow{2}{*}{$\begin{array}{l}\text { Yhteistoiminnallisuus } \\
\text { Cooperativeness }\end{array}$} & \multicolumn{3}{|c|}{ Peltoala ha Arable area ha } & \multirow{2}{*}{$\begin{array}{l}\text { Yht. } \\
\text { Total }\end{array}$} \\
\hline & $1-9.9$ & $10-19.9$ & $20-$ & \\
\hline 0 & 39 & 22 & 39 & 100 \\
\hline 1 & 55 & 28 & 17 & 100 \\
\hline 2 & 42 & 39 & 19 & 100 \\
\hline 3 & 33 & 31 & 36 & 100 \\
\hline \multirow[t]{2}{*}{$\begin{array}{l}\text { Yht. Total } \\
\text { N }\end{array}$} & $\begin{array}{c}44 \\
(87)\end{array}$ & $\begin{array}{c}30 \\
(60)\end{array}$ & $\begin{array}{c}26 \\
(53)\end{array}$ & $\begin{array}{c}100 \\
(200)\end{array}$ \\
\hline & \multicolumn{2}{|c|}{$\chi^{2}=12.7677$} & $<.05$ & \\
\hline
\end{tabular}

Tarkempaan erittelyyn pääsemiseksi on seikkaperäisemmän huomion kohteeksi otettu vielä kolme yleisintä yhteistoiminnan muotoa: työnvaihto, koneiden vaihto ja koneiden yhteisomistus. Koska koneiden + työn vaihto on eräänlainen sekamuoto ja koska muut yhteistoiminnan muodot ovat harvinaisia, ei ne pois jättämällä menetä kovin paljon, mutta sen sijaan saavutetaan etua voitaessa verrata mainittuja kolmea muotoa keskenään.

Taulukossa 3 korreloidaan peltoala ja yhteistoiminnallisuus. Tilastollisesti melkein merkitsevä jakautuma ei kuitenkaan ole selväsuuntainen. Suurimmat tilat näyttävät joko olevan kokonaan syrjässä yhteistoiminnasta tai osallistuvan siihen erittäin voimakkaasti, ja pienimmät tilat vastaavasti ovat yhteistoiminnallisuudessaan keskiluokissa.

Taulukko 4. Osallistuminen kolmeen yhteistoimintamuotoon peltoalaryhmittäin.

Table 4. Participation in the three fields of cooperation according to arable area of farms.

\begin{tabular}{|c|c|c|c|c|}
\hline \multirow[t]{2}{*}{$\begin{array}{l}\text { Peltoala ha } \\
\text { Arable area ha }\end{array}$} & \multicolumn{3}{|c|}{$\begin{array}{c}\text { Prosenttia tiloista osallistuu } \\
\text { Per cent of farms participating in }\end{array}$} & \\
\hline & $\begin{array}{l}\text { työnvaihtoon } \\
\text { exchange of labour }\end{array}$ & $\begin{array}{c}\text { koneiden } \\
\text { yhteisomistukseen } \\
\text { co-ownership of } \\
\text { machinery }\end{array}$ & $\begin{array}{l}\text { koneiden vaihtoon } \\
\text { exchange of machinery }\end{array}$ & \\
\hline $1-9.9$ & 61 & 40 & 20 & \\
\hline $10-19.9$ & 55 & 52 & 27 & \\
\hline $20-$ & 34 & 45 & 40 & \\
\hline Yht. Total & 52 & 45 & 27 & \\
\hline
\end{tabular}


Kolmen yhteistoimintamuodon läheisempi tarkastelu ja keskinäinen vertailu paljastaa mielenkiintoisia eroja peltoalaluokkien välillä. Taulukko 4 osoittaa osallistumisen eri yhteistoimintamuotoihin. Niinpä esim. 1-9 ha:n tiloista $61 \%$ osallistuu työnvaihtoon ja jäännös, $39 \%$ ei osallistu. Työnvaihto näyttää olevan pikkutilojen suosima yhteistoiminnan muoto, suurimmat puolestaan vaihtavat koneita. Riippuvuus selittyy osittain pientilojen isäntien korkeammasta keski-iästä: työnvaihto on traditionaalinen yhteistoiminnan muoto, joka elää voimakkaammin vanhemman sukupolven keskuudessa. Vaikuttavampana tekijänä lienee kumminkin tiloilla käytettävissä oleva työvoima. Alle 10 ha:n tiloilla on nimittäin tilalla vakinaisesti työskenteleviä keskimäärin 2.1 henkeä tilaa kohti, 10-19 ha:n tiloilla 2.5 henkeä ja yli 20 ha:n tiloilla 3.0 henkeä tilaa kohti. Pienemmillä tiloilla on siis työvoimaa hehtaaria kohti tuntuvasti enemmän.

Taulukko 5. Tilojen prosenttinen jakautuma yhteistoiminnallisuuden ja viljelijän iän mukaan. Table 5. Per cent distribution of farms according to cooperativeness and age of farmer.

\begin{tabular}{|c|c|c|c|c|}
\hline \multirow[t]{2}{*}{$\begin{array}{l}\text { Yhteistoiminnallisuus } \\
\text { Cooperativeness }\end{array}$} & \multicolumn{3}{|c|}{$\begin{array}{c}\text { Viljelijän ikä vuosia } \\
\text { Age of farmer }\end{array}$} & \multirow[t]{2}{*}{$\begin{array}{l}\text { Yht. } \\
\text { Total }\end{array}$} \\
\hline & -45 & $45-54$ & $55-$ & \\
\hline 0 & 20 & 37 & 43 & 100 \\
\hline 1 & 28 & 22 & 50 & 100 \\
\hline 2 & 38 & 23 & 38 & 100 \\
\hline 3 & 55 & 31 & 14 & 100 \\
\hline \multirow[t]{2}{*}{$\begin{array}{l}\text { Yht. Total } \\
\text { N }\end{array}$} & $\begin{array}{c}34 \\
(69)\end{array}$ & $\begin{array}{c}28 \\
(55)\end{array}$ & $\begin{array}{c}38 \\
(76)\end{array}$ & $\begin{array}{c}100 \\
(200)\end{array}$ \\
\hline & \multicolumn{3}{|c|}{$\chi^{2}=20.4561$} & \\
\hline
\end{tabular}

Viljelijän iän ja yhteistoiminnallisuuden välillä vallitsee tilastollisesti merkitsevä riippuvaisuussuhde (taulukko 5). Vanhemmat ikäluokat ovat yleensä enemmän syrjässä yhteistoiminnasta kun taas nuoremmat useammin kuuluvat intensiivisen yhteistoiminnan ryhmiin. Niinpä täysin syrjässä olevista isännistä on alle 45 vuotiaita vain $20 \%$, mutta kolmeen tai useampaan yhteistoimintaryhmään kuuluvista on samanikäisiä peräti $55 \%$.

Taulukko 6 vielä täsmentää kuvaa iän ja yhteistoiminnallisuuden keskinäisestä riippuvuudesta. Esim. alle 35-vuotiaista viljelijöistä $63 \%$ on työnvaihdossa, ja loput (100-63) $37 \%$ ei harrasta työnvaihtoa.

Taulukko 6:n kaikissa sarakkeissa luvut pienenevät alaspäin, kuten odotettua iän ja yhteistoiminnallisuuden korrelaation vuoksi. Kuitenkin viimeisen sarakkeen kohdalla putoaminen on voimakkaampaa. Koneiden vaihto on siis se yhteistoiminnan muoto, missä korrelaatio on voimakkainta, missä siis nuorten ja vanhain viljelijöiden erot ovat suurimmat.

Tilojen koneistumisastetta mitattiin tutkimuksessa laskemalla tilalla käytettyjen uudenaikaisten, moottorikäyttöisten koneiden luku. Huomioon otettavia koneita olivat mm. traktori, niittokone, kylvökone ja perunannostokone jos ne olivat traktorivetoisia, leikkuupui- 
Taulukko 6. Osallistuminen kolmeen yhteistoimintamuotoon ikäryhmittäin.

Table 6. Participation in the three fields of cooperation according to age of farmer.

\begin{tabular}{|c|c|c|c|}
\hline \multirow[t]{2}{*}{$\begin{array}{l}\text { Viljelijän ikä } \\
\text { Age of farmer }\end{array}$} & \multicolumn{3}{|c|}{$\begin{array}{l}\text { Prosenttia viljelijöistä osallistuu } \\
\text { Per cent of farmers participating in }\end{array}$} \\
\hline & $\begin{array}{l}\text { työnvaihtoon } \\
\text { exchange of labour }\end{array}$ & $\begin{array}{c}\text { koneiden } \\
\text { yhteisomistukseen } \\
\text { co-ownership of } \\
\text { machinery }\end{array}$ & $\begin{array}{l}\text { koneiden vaihtoon } \\
\text { exchange of machinery }\end{array}$ \\
\hline Alle Under 35 & 63 & 63 & 58 \\
\hline $35-44$ & 63 & 55 & 37 \\
\hline $45-54$ & 49 & 42 & 25 \\
\hline $55-64$ & 45 & 39 & 16 \\
\hline Yli Over 64 & 43 & 32 & 11 \\
\hline Yht. Total & 52 & 45 & 27 \\
\hline
\end{tabular}

muri, konekuivuri, lypsykone, moottorisaha jne. Koneistumisaste ei kuitenkaan näyttänyt olevan riippuvainen yhteistoiminnallisuudesta, sillä koneistetut tilat ja koneistamattomat tilat sijoittuivat jokseenkin tasaisesti yhteistoiminnallisuuden luokkiin.

Toinen yhdistetty muuttuja, jota tutkimuksessa käytettiin, oli uudistuksellisuus. Sitä mitattiin Guttman-asteikolla, jonka 6 osiota olivat muutos peltoviljelyssä, muutos karjamäärässä, muutos karjatalouden tuotantosuunnassa, kiinteiden laitteiden hankkiminen tilalle, maanparannustyöt ja tilan rakennusten muutos. Asteikon toistettavuuskerroin oli .88.

Taulukko 7 ei tarjoa nähtäväksi mitään selväsuuntaista riippuvuutta. Uudistuksellisuudessa selvästi muita alhaisemmalla tasolla ovat yhteen yhteistoimintaryhmään kuuluvat, ja korkeimmalla tasolla 3 t. useampaan yhteistoimintaryhmään kuuluvat.

Taulukko 7. Tilojen prosenttinen jakautuma yhteistoiminnallisuuden ja uudistuksellisuuden mukaan. Table 7. Per cent distribution of farms according to cooperativeness and innovativeness.

\begin{tabular}{|c|c|c|c|c|}
\hline \multirow{2}{*}{$\begin{array}{l}\text { Yhteistoiminnallisuus } \\
\text { Cooperativeness }\end{array}$} & \multicolumn{3}{|c|}{ Uudistuksellisuus Innovativeness } & \multirow{2}{*}{$\begin{array}{l}\text { Yht. } \\
\text { Total }\end{array}$} \\
\hline & $\begin{array}{l}\text { alin ryhmä } \\
\text { lowest group }\end{array}$ & $\begin{array}{l}\text { keskiryhmã } \\
\text { middle group }\end{array}$ & $\begin{array}{l}\text { ylin ryhmä } \\
\text { highest group }\end{array}$ & \\
\hline 0 & 37 & 24 & 39 & 100 \\
\hline 1 & 55 & 20 & 25 & 100 \\
\hline 2 & 40 & 27 & 33 & 100 \\
\hline 3 & 17 & 38 & 45 & 100 \\
\hline $\begin{array}{l}\text { Yht. Total } \\
\mathrm{N}\end{array}$ & $\begin{array}{c}39 \\
(78)\end{array}$ & $\begin{array}{c}27 \\
(53)\end{array}$ & $\begin{array}{c}34 \\
(69)\end{array}$ & $\begin{array}{c}100 \\
(200)\end{array}$ \\
\hline
\end{tabular}




\section{Yhteistoimintakumppanit}

Otokseen kuuluvilla viljelijöillä on keskimäärin 2.2 työnvaihtokumppania, 2.1 koneidenvaihtokumppania ja 2.3 kumppania koneiden yhteisomistusryhmässä eli konekimpassa, kuten viljelijät itse sitä nimittävät. Eroja kumppanien lukumäärässä peltoalaryhmittäin tai ikäryhmittäin ei ole havaittavissa.

Taulukossa 8 korreloidaan yhteistoimintaan osallistuvien viljelijöiden peltoalat. Suurimmat prosenttiluvut ovat taulukon diagonaalin läheisyydessä, mikä osoittaa korrelaation olemassaolon. Samankokoiset tilat siis jossain määrin ovat taipuvaisia etsimään toisiaan yhteistoiminnassa. Hajaantuma on kuitenkin suuri, sillä taulukosta nähdään joka peltoalaryhmän olevan yhteistoiminnassa jokaisen muun kanssa. Esim. 1-4 ha:n tilojen viljelijöillä on 11 sellaista kumppania, joiden peltoala on yli 30 ha. Tilakoko on siis yksi yhteistoimintaan vaikuttava, mutta ei ilmeisestikään mikään ratkaiseva tekijä.

Verrattaessa kolmea yhteistoiminnan muotoa keskenään jää vaikutelmaksi se, että koneiden yhteisomistus esiintyy useamman samankokoisten tilojen, ja työnvaihto ja koneiden vaihto lukuisammin erikokoisten tilojen välillä.

Taulukko 8. Yhteistoimintakumppanien prosenttinen jakautuma peltoalan mukaan.

Table 8. Per cent distribution of farmers' cooperation partners according to arable area.

\begin{tabular}{|c|c|c|c|c|c|c|c|}
\hline \multirow[t]{2}{*}{$\begin{array}{l}\text { Haastateltavan peltoala ha } \\
\text { Arable area of interviewee ha }\end{array}$} & \multicolumn{6}{|c|}{$\begin{array}{c}\text { Haastateltavan yhteistoimintakumppanien peltoala } \\
\text { Arable area of interviewees' partners }\end{array}$} & \multirow[t]{2}{*}{$\begin{array}{l}\text { Yht. } \\
\text { Total }\end{array}$} \\
\hline & $1-4.9$ & $5-9.9$ & $10-14.9$ & $15-19.9$ & $20-29.9$ & $30-$ & \\
\hline $1-4.9$ & 19 & 33 & 14 & 17 & 6 & 11 & 100 \\
\hline $5-9.9$ & 20 & 41 & 23 & 10 & 4 & 1 & 100 \\
\hline $10-14.9$ & 8 & 27 & 36 & 17 & 6 & 6 & 100 \\
\hline $15-19.9$ & 3 & 32 & 26 & 23 & 3 & 12 & 100 \\
\hline $20-29.9$ & 7 & 20 & 4 & 10 & 33 & 26 & 100 \\
\hline $30-$ & 9 & 9 & 25 & 12 & 20 & 25 & 100 \\
\hline $\begin{array}{l}\text { Yht. Total } \\
\text { N }\end{array}$ & $\begin{array}{r}12 \\
(64)\end{array}$ & $\begin{array}{c}29 \\
(153)\end{array}$ & $\begin{array}{c}24 \\
(127)\end{array}$ & $\begin{array}{c}14 \\
(72)\end{array}$ & $\begin{array}{c}10 \\
(53)\end{array}$ & $\begin{array}{c}10 \\
(52)\end{array}$ & $\begin{array}{c}100 \\
(521)\end{array}$ \\
\hline
\end{tabular}

Suurin piirtein joka kolmas kumppaneista on sukulainen ja pääosa sukulaisista on lähisukua. Yleisimmät yhdistelmät ovat isä ja poika, veljekset keskenään ja veli ja lanko. Sukulaisten prosenttinen osuus ei eroa kolmen tarkemmin tutkitun yhteistoimintamuodon välillä.

Taulukko 9 osoittaa, että peltoala ja sukulaisuus ovat yhteydessä keskenään. Isommilla tiloilla ovat sukulaiset yhteistoimintakumppaneina yleisempiä kuin pienillä. - Myös ikä ja sukulaisuus ovat yhteydessä keskenään, se nähdään taulukosta 10. Nuoremmat ikäluokat tuntuvat suosivan sukulaisiaan enemmän kuin vanhemmat.

\section{Asenteet ja yhteistoiminta}

A senteet ma a t a lou te e n y le ensä. Helposti mieleen tuleva olettamus on, että yhteistoimintaa harjoittavat ovat innokkaampia maanviljelijöitä, »maahenkisem- 
Taulukko 9. Yhteistoimintakumppanien prosenttinen jakautuma peltoalan ja sukulaisuuden mukaan.

Table 9. Per cent distribution of farmers' partners in cooperation according to kinship and arable area.

\begin{tabular}{lccc}
\hline $\begin{array}{l}\text { Peltoala ha } \\
\text { Arable area ha }\end{array}$ & $\begin{array}{c}\text { Sukulaiset } \\
\text { Kinship }\end{array}$ & $\begin{array}{c}\text { Ei-sukulaiset } \\
\text { Non-kinship }\end{array}$ & $\begin{array}{c}\text { Yht. } \\
\text { Total }\end{array}$ \\
\hline $1-9.9$ & 29 & 71 & 100 \\
$10-19.9$ & 26 & 74 & 100 \\
$20-$ & 45 & 55 & 100 \\
\hline Yht. Total & 32 & 68 & 100 \\
N & $(169)$ & $(362)$ & $(531)$ \\
& $\chi^{2}=14.3262$ & P $<.001$ &
\end{tabular}

Taulukko 10. Yhteistoimintakumppanien prosenttinen jakautuma viljelijän iän ja sukulaisuuden mukaan. Table 10. Per cent distribution of farmers' partners in cooperation according to age and kinship.

\begin{tabular}{lccc}
\hline $\begin{array}{l}\text { Viljelijän ikä } \\
\text { Age of farmer }\end{array}$ & $\begin{array}{c}\text { Sukulaiset } \\
\text { Kinship }\end{array}$ & $\begin{array}{c}\text { Ei-sukulaiset } \\
\text { Non-kinship }\end{array}$ & $\begin{array}{c}\text { Yht. } \\
\text { Total }\end{array}$ \\
alle-under 35 & 47 & 53 & 100 \\
$35-44$ & 33 & 67 & 100 \\
$45-54$ & 27 & 73 & 100 \\
$55-64$ & 27 & 73 & 100 \\
yli - over & 30 & 69 & 100 \\
\hline Yht. Total & 31 & 69 & 100 \\
N & $(169)$ & $(362)$ & $(531)$ \\
& & &
\end{tabular}

Taulukko 11. Viljelijöiden prosenttinen jakautuma yhteistoiminnallisuuden ja maataloudesta luopumisen halun mukaan.

Table 11. Per cent distribution of farmers according to cooperativeness and willingness to abandon agriculture.

\begin{tabular}{lcccc}
\hline $\begin{array}{l}\text { Yhteistoiminnallisuus } \\
\text { Cooperativeness }\end{array}$ & $\begin{array}{c}\text { Ei halua luopua } \\
\text { tilastaan } \\
\text { Unwilling }\end{array}$ & $\begin{array}{c}\text { Ei osaa sanoa } \\
\text { No opinion }\end{array}$ & $\begin{array}{c}\text { Haluaa luopua } \\
\text { tilastaan } \\
\text { Willing }\end{array}$ & $\begin{array}{c}\text { Yht. } \\
\text { Total }\end{array}$ \\
\hline & 46 & 28 & 26 & 100 \\
1 & 58 & 22 & 20 & 100 \\
2 & 52 & 15 & 33 & 100 \\
3 & 55 & 26 & 19 & 100 \\
\hline Yht. Total & 53 & 22 & 23 & 100 \\
N & $(106)$ & $(45)$ & $(49)$ & $(200)$ \\
& & & &
\end{tabular}


Taulukko 12. Viljelijöiden prosenttinen jakautuma yhteistoiminnallisuuden ja sen mukaan luuleeko pysyvänsä maanviljelijänä 65-vuotiaaksi asti.

Table 12. Per cent distribution of farmers according to cooperativeness and willingness to continue farming until the age of 65 .

\begin{tabular}{lcccc}
\hline $\begin{array}{l}\text { Yhteistoiminnallisuus } \\
\text { Cooperativeness }\end{array}$ & $\begin{array}{c}\text { Ei luule pysy- } \\
\text { vänsä } \\
\text { Unwilling }\end{array}$ & $\begin{array}{c}\text { Ei osaa sanoa } \\
\text { No opinion }\end{array}$ & $\begin{array}{c}\text { Luulee pysyvänsä } \\
\text { Willing }\end{array}$ & $\begin{array}{c}\text { Yht. } \\
\text { Total }\end{array}$ \\
\hline & 8 & 8 & 84 & 100 \\
1 & 10 & 4 & 86 & 100 \\
2 & 4 & 11 & 85 & 100 \\
3 & 7 & 10 & 83 & 100 \\
\hline Yht. Total & 8 & 8 & 84 & 100 \\
N & $(13)$ & $(14)$ & $(146)$ & $(173)$ \\
& & & &
\end{tabular}

Taulukko 13. Viljelijöiden prosenttinen jakautuma yhteistoiminnallisuuden ja pojalle annettavan neuvon mukaan.

Table 13. Per cent distribution of farmers according to cooperativeness and preference for agricultural work for their sons.

\begin{tabular}{lccc}
\hline \multirow{2}{*}{$\begin{array}{c}\text { Yhteistoiminnallisuus } \\
\text { Cooperativeness }\end{array}$} & \multicolumn{2}{c}{$\begin{array}{c}\text { Neuvoo poikaansa valitsemaan } \\
\text { Preference for }\end{array}$} & \multirow{2}{*}{$\begin{array}{c}\text { Yht. } \\
\text { Total }\end{array}$} \\
\cline { 2 - 3 } & $\begin{array}{c}\text { maataloudellisen } \\
\text { ammatin } \\
\text { agricultural } \\
\text { work }\end{array}$ & $\begin{array}{c}\text { ei-maataloudellisen } \\
\text { ammatin } \\
\text { non-agricultural } \\
\text { work }\end{array}$ & \\
\hline 0 & 75 & 25 & 100 \\
1 & 45 & 55 & 100 \\
2 & 68 & 32 & 100 \\
3 & 52 & 48 & 100 \\
\hline Yht. Total & 59 & 41 & 100 \\
N & $(63)$ & $(44)$ & $(107)$ \\
& $\chi^{2}=6.5127$ & P $<.10$ & \\
\hline
\end{tabular}

piä». Asennetta maatalouteen yleensä mitattiin tässä tutkimuksessa kolmea kysymystä käyttäen. Haastateltavia pyydettiin, yksi viidestä vaihtoehdosta valitsemalla, ilmaisemaan halunsa luopua maatalouden harjoittamisesta, jos he muunlaisessa työssä voisivat ansaita $15 \%$ enemmän kuin tilallaan ja jos he voisivat myydä tilansa hyvästä hinnasta. Taulukossa 11 on esitetty vastaukset tähän kysymykseen ryhmittelemällä vastaukset »ei halua», »ei osaa» ja "haluaa» -luokkiin. Toiseksi haastateltavia pyydettiin ilmaisemaan, missä määrin he halusivat jatkaa maanviljelijänä 65-vuotiaiksi asti. Vastauksista (taulukko 12) puuttuu kuitenkin 27 viljelijää, koska he olivat jo täyttäneet 65 vuotta. Viljelijöiden korkea keskiikä muutenkin vähentää kysymyksen tehokkuutta mittarina; 50-vuotias tuskin enää reaali- 
sesti voi ajatella ammatin vaihtoa vaikka haluaisikin. Kolmas kysymys tiedusteli sitä neuvoa, jonka haastateltava antaisi, jos hänen kouluakäyvä tai kotona nyt työskentelevä poikansa harkitsisi siirtymistään ei-maataloudelliseen ammattiin ja kysyisi isänsä mielipidettä. Vain 107 viljelijällä oli poikia k.o. iässä.

Voimakas yhteistoiminnallisuus ei aineistossa näy merkitsevän innostusta maatalouteen. Taulukoissa 11 ja 12 tilastollinen testi ei osoita minkäänlaista riippuvuutta. Taulukossa 13 riippuvuus on melkein merkitsevä, mutta negatiivinen. Intensiivisesti yhteistoiminnassa olevat viljelijät siis neuvovat poikiaan siirtymään pois maataloudesta jossain määrin useammin kuin yhteistoimiin osallistumattomat isännät.

Asenteet nykyis e en y teistoiminta a n. Yhteistoimintaryhmät syntyvät ilmeisesti jossain määrin ilman pitkän tähtäyksen suunnitelmia. Ainakin $53 \%$ yhteistoimintaa harjoittavasta viljelijästä ilmoitti, että yhteistoiminta sitä aloitettaessa oli tarkoitettu tilapäisluontoiseksi, 39 prosentin ilmoittaessa, että pysyväisluontoisesta järjestelystä jo alun perin oli kysymys. Jos yhteistoiminta pitäisi aloittaa uudelleen, $11 \%$ viljelijöistä ei lainkaan aloittaisi, $5 \%$ alkaisi hieman toisella lailla ja $84 \%$ aloittaisi yhteistoimintansa suurin piirtein vallitsevaan tapaan. Yhteistoiminta on $5 \%$ viljelijöistä rajoittanut itsemääräämisoikeutta tai vapautta, muilla ei tässä suhteessa ole ollut mitään vaikutuksia.

Viljelijöiltä myös kysyttiin yhteistoiminnan kielteisiä puolia. Vastaukset on luokiteltu (taulukko 14) kahteen ryhmään: luonteeltaan selvästi sosiaaliset, ihmissuhteita koskevat epäkohdat ja muut. Ryhmä »muut» jokseenkin varmasti sisältää myös sosiaalisia epäkohtia, mutta niitä ei voitu erottaa vastauksen epätäsmällisyyden tai puutteellisuuden takia. Selvästi taloudellisia epäkohtia mainittiin vain muutamia.

Taulukko 14. Yhteistoiminnan epäkohdat.

Table 14. Disadvantages of cooperation.

Viljelijöiden lukumäärä

Number of farmers

Ei mainitse mitään epäkohtia Does not list any disadvantages $\quad 79$

Mainitsee sosiaalisia epäkohtia Lists social considerations $\quad 32$

Mainitsee muita epäkohtia Lists other negative points 43

Ei yhteistoiminnassa No cooperation $\quad 46$

200

Yli puolet yhteistoimintaviljelijöistä ei mainitse mitään epäkohtia. Taulukko 14:n perusteella on mahdollista päätellä, että yhteistoiminnan epäkohdista luonteeltaan sosiaaliset ovat ensi sijalla.

Epäkohtien mainitseminen ei korreloidu peltoalan kanssa, s.o. pienviljelijät mainitsevat niitä yhtä useasti kuin suurempien tilojen isännätkin. Liioin ei viljelijän iän ja epäkohtien havaitsemisen välillä ole riippuvuutta aineistossa. Yhteistoiminnan intensiteettikään ei näy vaikuttavan epäkohtien syntymiseen, sillä yhteen ryhmään kuuluvat viljelijät mainitsevat epäkohtia (ja myös sosiaalisia epäkohtia) suunnilleen yhtä useasti kuin kolmeen yhteistoimintaryhmään kuuluvatkin.

Taulukko 15 esittää vielä viljelijöiden asenteet kolmea yhteistoimintamuotoa kohtaan. 
Taulukko 15. Viljelijöiden asenteet kolmea yhteistoiminnan muotoa kohtaan.

Table 15. Farmers' attitudes towards the three fields of cooperation.

\begin{tabular}{|c|c|c|c|c|c|}
\hline \multirow[t]{2}{*}{$\begin{array}{l}\text { Yhteistoiminnan muoto } \\
\text { Field of cooperation }\end{array}$} & \multicolumn{3}{|c|}{$\begin{array}{l}\% \text { viljelijöistä aikoo yhteistoimintaa } \\
\text { Per cent of farmers intending to } \\
\end{array}$} & \multirow[t]{2}{*}{$\begin{array}{l}\text { Ei osaa sanoa } \\
\text { No opinion }\end{array}$} & \multirow[t]{2}{*}{$\begin{array}{l}\text { Yht. } \\
\text { Total }\end{array}$} \\
\hline & $\begin{array}{l}\text { tehostaa } \\
\text { intensify }\end{array}$ & $\begin{array}{l}\text { jatkaa } \\
\text { continue }\end{array}$ & $\begin{array}{l}\text { lopettaa } \\
\text { stop }\end{array}$ & & \\
\hline $\begin{array}{l}\text { Työnvaihto Exchange of labor } \\
\text { Koneiden vaihto }\end{array}$ & 4 & 82 & 9 & 6 & 100 \\
\hline $\begin{array}{l}\text { Exchange of machinery } \\
\text { Koneiden yhteisom. }\end{array}$ & 11 & 74 & 6 & 9 & 100 \\
\hline Co-ownership of machinery & 3 & 89 & 3 & 6 & 100 \\
\hline $\begin{array}{l}\text { Yht. Total } \\
\text { N }\end{array}$ & $\begin{array}{c}5 \\
(13)\end{array}$ & $\begin{array}{c}82 \\
(202)\end{array}$ & $\begin{array}{c}6 \\
(15)\end{array}$ & $\begin{array}{c}7 \\
(16)\end{array}$ & $\begin{array}{r}100 \\
(246)\end{array}$ \\
\hline
\end{tabular}

Suuri enemmistö aikoo jatkaa edelleen, ja lienee siis tyytyväinen tätänykyiseen yhteistoimintaansa. Työnvaihtoa pyritään useimmin lopettamaan ja koneiden vaihtoa lisäämään; seikka joka käy ymmärrettäväksi koneistuvan ja ihmistyövoimaa vähentävän maataloutemme yhteydessä.

Asenteet yhteistoiminnan tehostamista kohtaan. Jotta voitiin mitata viljelijöiden asenteet yhteistoiminnan tehostamista kohtaan ja tämän asenteen riippuvuus nykyisen yhteistoiminnan asteesta, haastateltaville luettiin kuviteltu esimerkkitapaus, joka kuvasi intensiivistä yhteistyötä. Luettu katkelma oli seuraavanlainen.

Muutamat maanviljelijät ovat ostaneet useita kalliita koneita (esim. leikkuupuimurin ja traktorikaivurin) yhteisesti ja käyttãvät niitä sekä heillã jo ennestään olleita koneita ns. konerenkaan muodossa. Joka viikko he sopivat keskenään, mitä töitä suoritetaan kunkin tilalla ja miten ne suoritetaan. Paljon työtä vaativissa tehtävissä he auttavat toisiaan perheenjäsenten ja tiloilla olevan palkkatyövoiman avulla.

Taulukko 16. Viljelijäin asenteet kuviteltuun esimerkkitapaukseen.

Table 16. Farmers' attitudes towards the fictive case of cooperation.

Ei ole riittävän pitkälle viety, tarpeeksi tehokas ratkaisu

Solution does not go far enough

On hyvä ratkaisu

A good solution

Melko hyvä ratkaisu, mutta on sillä muutamia heikkouksiakin

$A$ rather good solution with some disadvantages

Tämän ratkaisun kielteiset puolet ovat suuremmat kuin myönteiset

The disadvantages of the solution are not outweighed by the advantages

On huono ratkaisu

A poor solution 
Lukemisen jälkeen haastateltavat saivat ilmaista oman asenteensa valitsemalla jonkin heille ojennetussa kortissa olleista viidestä vaihtoehdosta. Taulukko 16 esittää vaihtoehdot ja vastausten lukumäärän.

Puolet viljelijöistä suhtautuu myönteisesti esimerkkitapaukseen, joka edustaa intensiivisempää yhteistyötä kuin tutkimuspaikkakunnalla esiintyvä. Taulukko 17 esittää vastaukset yhteistoiminnallisuuden mukaan järjestettyinä. Myönteiseksi asenteeksi on katsottu taulukon 16 vaihtoehdot $1-3$ ja kielteiseksi $4-5$. Ne neljäkymmentä viljelijää, jotka eivät

Taulukko 17. Viljelijöiden prosenttinen jakautuma yhteistoiminnallisuuden ja esimerkkitapausta kohtaan ilmaistujen asenteiden mukaan.

Table 17. Per cent distribution of farmers according to cooperativeness and attitude towards the fictive case.

\begin{tabular}{|c|c|c|c|}
\hline \multirow{2}{*}{$\begin{array}{l}\text { Yhteistoiminnallisuus } \\
\text { Cooperativeness }\end{array}$} & \multicolumn{2}{|c|}{ Asenne Attitude } & \multirow{2}{*}{$\begin{array}{l}\text { Yht. } \\
\text { Total }\end{array}$} \\
\hline & $\begin{array}{l}\text { myönteinen } \\
\text { positive }\end{array}$ & $\begin{array}{l}\text { kielteinen } \\
\text { negative }\end{array}$ & \\
\hline 0 & 53 & 47 & 100 \\
\hline 1 & 49 & 51 & 100 \\
\hline 2 & 61 & 39 & 100 \\
\hline 3 & 88 & 12 & 100 \\
\hline \multirow[t]{2}{*}{$\begin{array}{l}\text { Yht. Total } \\
\mathrm{N}\end{array}$} & $\begin{array}{l}61 \\
(98)\end{array}$ & $\begin{array}{c}39 \\
(62)\end{array}$ & $\begin{array}{c}100 \\
(160)\end{array}$ \\
\hline & $\chi^{2}=13.955$ & $\mathrm{P}<.0$ & \\
\hline
\end{tabular}

katsoneet esimerkkitapauksen ollenkaan soveltuvan heidän tilaansa ja luopuivat kannanotosta, on jätetty pois.

Taulukko kertoo selvästä ja tilastollisesti merkitsevästä riippuvaisuussuhteesta: asenteen

Taulukko 18. Viljelijöiden prosenttinen jakautuma yhteistoiminnallisuuden ja osallistumishalukkuuden mukaan.

Table 18. Per cent distribution of farmers according to cooperativeness and willingness to participate in the fictive case of cooperation.

\begin{tabular}{cccc}
\hline $\begin{array}{c}\text { Yhteistoiminnallisuus } \\
\text { Cooperativeness }\end{array}$ & $\begin{array}{c}\text { Halukas } \\
\text { osallistumaan } \\
\text { Willing to } \\
\text { participate }\end{array}$ & $\begin{array}{c}\text { Haluton } \\
\text { osallistumaan } \\
\text { Unwilling to } \\
\text { participate }\end{array}$ & $\begin{array}{c}\text { Yht. } \\
\text { Total }\end{array}$ \\
\hline 0 & 20 & 80 & 100 \\
1 & 27 & 73 & 100 \\
2 & 38 & 62 & 100 \\
3 & 62 & 38 & 100 \\
\hline Yht. Total & 35 & 65 & 100 \\
N & $(71)$ & $(129)$ & $(200)$ \\
& $\chi^{2}=20.1124$ & P $<.001$ &
\end{tabular}


myönteisyys esimerkkitapausta kohtaan kasvaa oman yhteistoiminnan lisääntyessä. Haastateltavilta kysyttiin myös, haluaisivatko he itse osallistua esimerkkitapauksen kaltaisesti järjestettyyn yhteistoimintaan. Taulukossa 18 vastaukset.

Myös tässä taulukossa näkyy selvä ja tilastollisesti erittäin merkitsevä riippuvuussuhde. Mitä enemmän viljelijä itse on yhteistyössä sitä halukkaampi hän on osallistumaan esimerkkitapauksen tavoin järjestettyyn yhteistoimintaan. Voitaneen siis päätellä, että myönteinen suhtautuminen ja osallistumispäätös tehostettuun yhteistoimintaan viljelijöiden välillä ovat voimakkaasti riippuvia siitä, kuinka paljon viljelijällä ennestään on omia kokemuksia osallistumisestaan yhteistyöhön.

Lopuksi vielä tiedusteltiin viljelijäin asennetta hyvin intensiiviseen yhteistoimintaan esittämällä heille seuraava kysymys.

Mitä ajattelette sellaisesta mahdollisuudesta, että kaksi tai useampia tiloja yhdistettäisiin yhdeksi tuotantokokonaisuudeksi, jonka piirissä kukin entisistä viljelijöistä hoitaisi tietyn osan tehtävistä (esim. yksi karjatalouden, toinen pellot, kolmas metsät jne.)?

Tähän vapaavastauksiseen kysymykseen 24 viljelijää (12\%) vastasi selvästi myönteistä asennetta osoittavasti, 30 viljelijää (15\%) ei ilmaissut selvästi asennettaan ja loput eli 146 viljelijää $(73 \%)$ antoi selvästi ymmärtää kielteisen asenteensa. Ainakin puolessa kielteisistä vastauksista esiintyi sana »kolhoosi», käytettynä nimenomaan kielteissävyisesti. Taulukko 19 esittää vielä vastaukset yhteistoiminnallisuuden mukaan luokiteltuna.

Tämän kysymyksen vastauksissa ei enää esiinnykään rïppuvuutta yhteistoiminnallisuudesta. Tosin kolmeen ryhmään kuuluvilla myönteisten vastausten osuus on viisi prosenttiyksikköä korkeampi, mutta sittenkin jakautuma on jokseenkin tasainen.

Selitys taulukoiden 17 ja 18 ja toisaalta taulukon 19 väliseen suureen eroon lienee haettava yhteistyön laadusta. Oman riippumattomuutensa ja itsenäisyytensä säilyttäminen on tärkeätä suomalaiselle maanviljelijälle, ja pelko niiden menettämisestä useasti estää yhteistoimintaa kehittymästä. Taulukon 19 tarkoittama tilojen yhdistäminen merkitsisi voimakasta oman päätösvallan supistumista viljelijälle ja siksi siihen suhtaudutaan kielteisesti.

Taulukko 19. Viljelijäin prosenttinen jakautuma yhteistoiminnallisuuden sekä sen mukaan miten he asennoituvat tilojen yhdistämiseen yhdeksi tuotantokokonaisuudeksi.

Table 19. Per cent distribution of farmers according to cooperativeness and attitude towards uniting farms.

\begin{tabular}{lcccc}
\hline $\begin{array}{l}\text { Yhteistoiminnallisuus } \\
\text { Cooperativeness }\end{array}$ & $\begin{array}{c}\text { Kielteinen } \\
\text { asenne } \\
\text { Negative attitude }\end{array}$ & $\begin{array}{c}\text { Ei osaa sanoa } \\
\text { No opinion }\end{array}$ & $\begin{array}{c}\text { Myönteinen } \\
\text { asenne } \\
\text { Positive attitude }\end{array}$ & $\begin{array}{c}\text { Yht. } \\
\text { Total }\end{array}$ \\
\hline 0 & 65 & 22 & 13 & 100 \\
1 & 70 & 20 & 10 & 100 \\
2 & 84 & 6 & 10 & 100 \\
3 & 72 & 11 & 17 & 100 \\
\hline Yht. Total & 73 & 15 & 12 & 100 \\
N & $(146)$ & $(30)$ & $(24)$ & $(200)$ \\
& $\chi^{2}=8.2187$ & P $<.30$ &
\end{tabular}


Edellä selostettu tutkimus on kohdistunut 200 maanviljelijään keskiarvoa vauraammalla maatalousseudulla. Kolme neljästä viljelijästä oli yhteistoiminnassa muiden viljelijöiden kanssa. Joka kolmas yhteistoimintaryhmä oli ihmistyövoiman vaihtoa ja n. $60 \%$ kaikista ryhmistä oli tekemisissä maatalouskoneiden kanssa. Pienviljelijät vaihtoivat työtä, suuremmilla tiloilla yhteistyö useammin liittyi koneisiin. Nuoremmat ikäluokat enemmän suosivat yhteistyötä yleensä ja erityisesti koneiden vaihtoa. Yhteistoiminnan määrä ei ollut riippuvaisuussuhteessa tilan koneistumisasteeseen, mutta kylläkin jossain määrin isännän uudistuksellisuuteen.

Yhteistoiminnassa olivat kaikenkokoiset tilat keskenään, joskin yhteistoiminta hieman useammin tapahtui samankokoisten tilojen välillä. Suunnilleen joka kolmas kumppaneista oli sukulainen. Tilakoon kasvaessa tai isännän iän aletessa näytti sukulaisten osuus kasvavan.

Asenteet maatalouteen yleensä eivät näyttäneet riippuvan yhteistoiminnallisuudesta. Viljelijät olivat tyytyväisiä nykyiseen yhteistoimintaansa. Se ei ollut huomattavasti vähentänyt heidän itsenäisyyttään. Enemmistö ei maininnut mitään epäkohtia, ja melkein kaikki ajattelivat jatkaa vallitsevaa yhteistoimintaa. Mitä intensiivisemmin viljelijä oli yhteistoiminnassa, sitä myönteisemmin hän suhtautui yhteistoiminnan lisäämiseen. Mutta jos yhteistoiminta uhkasi supistaa hänen itsemääräämisoikeuttaan, hänen asenteensa muuttui kielteiseksi.

Yhteistoiminta maanviljelijöiden välillä on vanha perinne, joka on elänyt maatalouden voimakkaasta muuttumisesta huolimatta meidän päiviimme asti. Se on kyllä jossain määrin muuttunut, mm. koneiden vaihto ja koneiden yhteisomistus ovat tulleet uutena muotona työnvaihdon rinnalle. Mutta muuttuminen juuri osoittaa elinkelpoisuutta, joka mahdollistaa myös tietoisen muuttamisen nykyolosuhteisiin soveltuvaksi. Pienen tilakokomme takia nimenomaan koneistamisen kannattavuus muodostaa vaikean ongelman, jonka eräs ratkaisu saattaisi löytyä lisääntyvästä yhteistoiminnasta. Yhteistoiminta olisi siis taloudelliselta kannalta katsottuna hyvä ratkaisu. Mutta muotoja suunniteltaessa ja pyrittäessä elvyttämään on muistettava, että yhteistoiminta viljelijöiden välillä on ennen kaikkea sosiaalinen ilmiö. Jos se kyetään suunnittelemaan ja toteuttamaan siten, että sen piirissä vallitsevat ihmissuhteet ovat osallistujia tyydyttäviä, on yhteistoiminta mahdollista ja antaa myös hyvän taloudellisen tuloksen. Mutta jos ihmissuhteet ovat sopimattoman organisaatiomuodon tai taitamattoman asioiden hoitamisen tai osallistujien sopeutumattoman luonteen takia ristiriitaisia, ei yhteistoiminta onnistu hyvin eikä liioin johda hyvään taloudelliseenkaan tulokseen. 


\title{
SUMMARY
}

\section{COOPERATION BETWEEN FARMERS IN FINLAND}

\author{
KaUko Honkala
}

\author{
Institute of Social Research, Swedish University of Abo
}

This empirical study was made in an above-average agricultural municipality in South Finland by interviewing 200 farmers, selected at random from the municipality census list. Table 1 shows the arable areas of the sample farms, and the ages of the farmers. The subject matter of the study is cooperation between farmers. Table 2 shows the forms of cooperation and the number of farmers participating in each form. On the basis of the data on cooperation, a variable called cooperativeness is formed. In the analysis this variable is correlated to several other variables in order to establish the difference between cooperating and noncooperating farmers.

The arable area of the farm does not correlate strongly with cooperativeness (Table 3). Mediumsized farms are admittedly in the middle group in cooperativeness, while the largest farms either cooperate very intensively or not at all. Smallholders seem to exchange work, but on larger farms cooperation is more often connected with machines (Table 4). The younger the farmer the more cooperative he is, this being so especially with machines (Tables 5-6). Cooperation is not associated with the degree of mechanization of the farm, but a farmer's innovativeness is slightly correlated to his cooperativeness, especially in the highest group (Table 7).

The cooperative farmers have an average of 2.2 partners in exchange of labour, 2.1 partners in exchange of machinery, and 2.3 partners in co-ownership of machinery. Table 8 shows the arable areas of interviewees cross-tabulated with that of partners. It appears that in every farm-size class a farmer may have a partner, but cooperation on the other hand tends to exist between two farms of about the same size. Operators of large farms and younger farmers tend to have relatives as partners (Tables 9-10).

The attitudes of the farmers towards agriculture in general were ascertained by asking whether they would prefer to change over to non-agricultural work, whether they intended to continue farming until the age of 65 , and whether they preferred that their sons should choose a non-agricultural occupation (Tables 11-13). The farmers' attitudes towards agriculture are not in general related to his cooperativeness. Only in Table 13 is there a nearly significant correlation statistically of the most intensively cooperating farmers preferring a non-agricultural profession for their sons.

Cooperation between farmers seems to be somewhat fortuitous. Over half of the farmers stated that cooperation was, to start with, intended to be only provisional. Nevertheless the farmers seem quite satisfied with their present way of cooperation. Of the 154 cooperating farmers 79 do not list any disadvantages, while 75 farmers mention some negative points in cooperation. In regard to the future, it is hoped to intensify the exchange of machinery and to stop the exchange of labour.

To find out the farmers' attitudes towards an intensification of the cooperation, a fictive case of close cooperation was presented. Table 16 shows the distribution of the attitudes, and Table 17 the distribution as related to cooperativeness. It appears that an increase in the positiveness of the attitudes is positively related to the intensity of present cooperation. Willingness to participate in intensive cooperation as presented in the fictive case likewise increases with the cooperativeness of the farmer (Table 18). However, when cooperation begins to resemble collectivism the opinions of the farmers turn strongly negative (Table 19).

Cooperation between farmers is necessitated by economic considerations, yet favourable economic conditions do not automatically lead to a frictionless functioning of the cooperating group. More important by far are the personal characteristics of the group members, i.e. their view on cooperacion and their willingness to conform to written stipulations and the unwritten norms of their specific cooperation group. 